National Marine

Fisheries Service

NOAA
Fishery Bulletin

ar established in 1881 o
Spencer F. Baird

First U.S. Commissioner of Fisheries and founder of Fishery Bulletin
Abstract-Gulf menhaden (Brevoortia patronus) produce one of the largest U.S. fisheries, yet information on reproductive dynamics of the stock is sparse. Males and females reach $50 \%$ maturity at 140.8 and 137.2 $\mathrm{mm}$ fork length, respectively and recruit into the commercial fishery at this size. Analysis of fishery-dependent data from 1964 through 2014 indicated that somatic condition was lower during the late 1980s and late 2000 s and that reproductively active fish from 2014 were significantly larger and had greater gonadosomatic index values than those from 1964 through 1970. Histological analysis performed on fish from 2014 through 2016 revealed spawning-capable and actively spawning fish of both sexes from early October through midMarch. Females have indeterminate fecundity, are batch spawners, and spawn every 2.1-4.3 days, although oocyte recruitment shows some characteristics of determinate fecundity. Mean relative batch fecundity was 107.8 eggs/g ovary-free body weight (standard error 17.1). Estimates from age-structured assessment models based on updated fecundity and maturity measures resulted in a 100-1000x greater production of eggs than previous estimates. Model output, including the number-at-age, age-specific fishing-induced mortality, and spawners-per-recruit are sensitive to alterations in age-specific annual fecundity. Therefore, updated estimates of Gulf menhaden reproductive dynamics can affect assessments of the stock.

Manuscript submitted 1 August 2016 Manuscript accepted 28 March 2017. Fish. Bull. 115:284-299 (2017). Online publication date: 9 May 2017. doi: 10.7755/FB.115.3.2

The views and opinions expressed or implied in this article are those of the author (or authors) and do not necessarily reflect the position of the National Marine Fisheries Service, NOAA.

\title{
Reproductive dynamics of Gulf menhaden (Brevoortia patronus) in the northern Gulf of Mexico: effects on stock assessments
}

\author{
Nancy J. Brown-Peterson (contact author) ${ }^{1}$ \\ Robert T. Leaf ${ }^{1}$ \\ Amy M. Schueller ${ }^{2}$ \\ Michael J. Andres ${ }^{1}$ \\ Email address for contact author: nancy.brown-peterson@usm.edu \\ 1 Division of Coastal Sciences \\ School of Ocean Science and Technology \\ The University of Southern Mississippi \\ 703 East Beach Drive \\ Ocean Springs, Mississippi 39564 \\ Present address for contact author: Center for Fisheries Research and Development \\ Gulf Coast Research Laboratory \\ The University of Southern Mississippi \\ 703 East Beach Drive \\ Ocean Springs, Mississippi 39564 \\ 2 Beaufort Laboratory \\ Southeast Fisheries Science Center \\ National Marine Fisheries Service, NOAA \\ 101 Pivers Island Road \\ Beaufort, North Carolina 28516
}

Gulf menhaden (Brevoortia patronus), family Clupeidae, are exploited by an industrial purse seine fleet and a smaller purse-seine bait fleet in the northern Gulf of Mexico (GOM). The fishery comprises the largest catches, by weight, of any fishery in the lower contiguous United States (Vaughn et al., 2007; VanderKooy and Smith ${ }^{1}$. The majority of the commercial landings (>99\%) are harvested for the reduction fishery at 3 facilities based along the GOM coast (Moss Point, Mississippi, and Empire and Abbeville, Louisiana), which operates from the third Monday in April through

\footnotetext{
${ }^{1}$ VanderKooy, S. J., and J. W. Smith (eds.). 2015. The menhaden fishery of the Gulf of Mexico, United States: a regional management plan, 2015 rev. Gulf States Mar. Fish. Comm., No. 240, 200 p. Gulf States Mar. Fish. Comm., Ocean Springs, MS. [Available from website, accessed June 2016].
}

October 31 (Vaughan et al., 2007). Harvest data for Gulf menhaden are estimated from daily catch records. The most recent Gulf menhaden stock assessment was completed in $2013\left(\mathrm{SEDAR}^{2}\right)$ and updated in October 2016 (Schueller $\left.{ }^{3}\right)$. Although the fishery has economic and ecological importance, changes in the biological aspects of the stock in the past 5 decades of exploitation have not been described, particularly those related to reproduction.

2 SEDAR (Southeast Data, Assessment, and Review). 2013. SEDAR 32AGulf of Mexico menhaden stock assessment report, 422 p. SEDAR, North Charleston, SC. [Available from website, accessed June 2016].

3 Schueller, A. 2016. GDAR 02-Gulf menhaden stock assessment: 2016 update. Gulf States Mar. Fish. Comm., GSMFC No. 254, 65 p. GSMFC, Ocean Springs, MS. [Available from website.] 
Relatively little recent work has been done to describe the reproductive dynamics of Gulf menhaden. Gulf menhaden spawn offshore in high-salinity waters (Fore, 1970; Sogard et al., 1987). Larvae are transported to estuaries from late winter through early spring (Shaw et al., 1985; Govoni, 1997), and juveniles remain in the estuary until they move offshore the following fall. Females in spawning condition have been documented to occur from September to April, but the reported peak spawning season occurs between December and February (Combs, 1969; Lewis and Roithmayr, 1981). Gulf menhaden are batch spawners (Lewis and Roithmayr, 1981), but the duration of the spawning season, the frequency with which an individual spawns, and annual fecundity are not well known, but are likely age- and length-dependent (see Lowerre-Barbieri et al., 2011). Because accurate age-specific spawning seasonality, batch fecundity (BF), and estimates of spawning frequency have not been reported for Gulf menhaden, the fecundity estimates reported by Lewis and Roithmayr (1981), currently employed in the stock assessment model used for Gulf menhaden, may be inaccurate. Such inaccuracies can lead to a biased understanding of the reproductive capability of the stock.

Our objective is to determine the characteristics of the reproductive biology of Gulf menhaden in order to assess their effects on stock assessments and to understand historical patterns of reproductive output. We provide information on the reproductive biology of Gulf menhaden, including size-at-maturity, the duration and timing of the spawning season, individual ovarian and testicular dynamics, BF, and spawning frequency, and incorporate age-specific fecundity data into an agestructured stock assessment model to understand how updated estimates can change our understanding of the Gulf menhaden stock. Finally, we evaluate historic changes in the demographic characteristics of the Gulf menhaden stock by comparing data collected from the commercial fishery from 1964 through 2014. This research is intended to improve a general understanding of the dynamics of the Gulf menhaden stock and provide information for management.

\section{Materials and methods}

\section{Collection of samples}

Gulf menhaden were collected from Mississippi and Louisiana coastal waters of the northern GOM from August to October 2014, from January to June 2015, November 2015, and from January to February 2016. Samples were obtained opportunistically from purseseine boats at the Omega Protein reduction facility at Moss Point, Mississippi, during the commercial fishing season (from April to October) and from commercial shrimp trawls in February 2015. Gulf menhaden were also obtained during trawl and gillnet sampling by the Louisiana Department of Wildlife and Fisheries (LDWF) and the University of Southern Mississippi
(USM) Center for Fisheries Research and Development (CFRD) in the winter and early spring. When possible, biological data were collected from fish within $24 \mathrm{~h}$ of capture from fresh fish stored on ice. All collections obtained from LDWF, and some collections from Omega Protein, were frozen upon capture, and these specimens remained fully or partially frozen during the recording of biological data.

Fish were measured for fork length (FL) in millimeters and weighed (W) in grams, and scales were removed from along the lateral line, below the insertion of the dorsal fin, rinsed, and stored in paper coin envelopes for age determination, consistent with current fishery age-sampling methods. Sex was macroscopically determined, and gonads were removed and weighed (GW) to the nearest $0.01 \mathrm{~g}$. The gonadosomatic index (GSI) and condition factor $(K)$ were calculated as:

$$
\begin{aligned}
& G S I=(G W /(W-G W)) \times 100 \\
& \text { and } K=\left(W / F L^{3}\right) \times 100,000 .
\end{aligned}
$$

Gonads were macroscopically classified into reproductive phases according to the terminology of BrownPeterson et al. (2011), and a portion of the left gonad from each fish was placed into individually labeled cassettes and preserved in 10\% neutral buffered formalin for histological analysis. Gonadal tissue from frozen specimens was placed in cold $\left(4^{\circ} \mathrm{C}\right)$ formalin and allowed to thaw in the refrigerator in the fixative to minimize damage to the frozen tissues and improve the histological preparations.

\section{Age determination}

Individual ages were determined by methods consistent with the Gulf menhaden stock assessments (VanderKooy ${ }^{4}$. Collected scales were rinsed in warm tap water, dried, and mounted onto glass slides $(n=10$ scales/fish). Age estimates were determined by counting annuli on images that were projected by using an Eberbach $^{5}$ macro-projector (Eberbach Corp., Ann Arbor, MI) at $48 \times$ magnification. A birthdate of 1 January was assigned for all fish $\left(\mathrm{SEDAR}^{2}\right)$. Fish captured in January and February that had scales with a large margin beyond the last annulus were classified as a year older.

\section{Reproductive biology}

Histological processing of gonadal tissues followed standard techniques. Tissues were fixed for a minimum of 1 week, rinsed overnight in running tap water, dehydrated in a series of graded ethanols, and embed-

\footnotetext{
${ }^{4}$ VanderKooy, S. (ed.) 2009. A practical handbook for determining the ages of Gulf of Mexico fishes, 2nd ed. Gulf States Mar. Fish. Comm., Publ. No. 167, 136 p. Gulf States Mar. Fish. Comm., Ocean Spring, MS. [Available from website, accessed June 2016]

${ }^{5}$ Mention of trade names or commercial companies is for identification purposes only and does not imply endorsement by the National Marine Fisheries Service, NOAA.
} 
ded in paraffin. Tissues were cross sectioned at $4 \mu \mathrm{m}$ and stained with hematoxylin and eosin. Microscopic inspection of testicular and ovarian tissues and evaluation of spermatogenesis and oogenesis followed the method of Brown-Peterson et al. (2011). Reproductive phases were assigned to males and females (Brown-Peterson et al., 2011), and included immature, developing (with the early developing subphase), spawning capable (with the actively spawning sub-phase for females), regressing, and regenerating. Additionally, broad reproductive descriptors of males and females were defined as reproductively active (including the developing, spawning capable, and actively spawning phases) or reproductively inactive (including the immature, early developing, regressing, and regenerating phases).

Females assessed macroscopically to be in the actively spawning subphase were sampled for fecundity by placing a weighed portion $(0.01 \mathrm{~g})$ of the ovary into Gilson's fixative or 10\% neutral buffered formalin. Ovarian tissue fixed in Gilson's fixative remained in solution for a minimum of 3 months prior to analysis; tissue fixed in $10 \%$ formalin remained in solution 1 month before analysis. Tissues were rinsed overnight in running water and oocytes remaining attached to ovarian tissue were teased apart. The volumetric method (Bagenal and Braum, 1971) was used to determine $\mathrm{BF}$ (number of eggs), and 6 replicate samples of all oocytes $\geq 500 \mu \mathrm{m}$, representing oocytes undergoing oocyte maturation (OM), were counted. To determine the correct size of oocytes to count for fecundity determinations, all oocytes $>80 \mu \mathrm{m}$ from an actively spawning fish were counted and measured in a 1-mL subsample. Oocyte size-frequency graphs were constructed, and only oocytes $\geq 500 \mu \mathrm{m}$ that presented a distinct mode at the end of the distribution were counted. This largest batch of oocytes was verified histologically to be either hydrated or undergoing OM for each sample analyzed. Additionally, the oocyte size-frequency distribution of secondary growth oocytes $(>80 \mu \mathrm{m})$ of fish in the actively spawning sub-phase at the beginning (October) and end (March) of the reproductive season was plotted to identify the fecundity pattern (determinate or indeterminate) of Gulf menhaden, following procedures described by Lowerre-Barbieri et al. (2011).

Spawning frequency of females was determined by calculating the percentage of females in the spawning capable phase (including the actively spawning subphase) with 1) $\leq 24 \mathrm{~h}$ postovulatory follicle complex (POF) or 2) oocytes undergoing OM after procedures as outlined in Brown-Peterson and Warren (2001). Spawning frequency data were used in combination with $\mathrm{BF}$ data to estimate total annual fecundity.

\section{Using fecundity data in the stock assessment}

The Beaufort Assessment Model (BAM) is the primary assessment model used for the federal stock assessment of Gulf menhaden (Williams and Shertzer, 2015). Data inputs include a suite of fishery-independent and fishery-dependent data, and the model is age struc- tured. Aging error was included in the model, as in the "base" formulation of the BAM during the last benchmark assessment (see SEDAR ${ }^{2}$ for the aging error matrix). Natural mortality was assumed to be time invariant, but age varying. The sex ratio was fixed at 1:1 and the parameters of the von Bertalanffy growth function were estimated internally and constant. Fish were assumed to spawn on 1 January, and therefore all reproductive values in the stock assessment correspond to 1 January. The maturity ogive was fixed such that $0 \%$ of individuals were mature at age 0 and age 1 and $100 \%$ were mature at age 2 . Mean lengths at age on 1 January were used to calculate mean fecundity at age on 1 January. Recruitment was modeled with a Beverton-Holt stock recruitment curve and steepness was fixed at 0.75 . Selectivity for the commercial reduction fishery was assumed to be dome shaped and only age1 selectivity was estimated. Constant catchability was estimated for each of the 2 fishery-independent gears (gill and seine nets) used to sample the stock. Gillnet sampling targets age- 1 to $4+$ fish, whereas seine net sampling targets predominately age- 0 fish.

We compared the estimates from the "base" formulation of the BAM, that incorporates age-specific fecundity estimates from Lewis and Rothymayr (1981) and the maturity schedule described above, with BAM-derived estimates based on alternative formulations from reproductive dynamics described in this work. We incorporated 2 changes to the input variables in the BAM model: the magnitude of individual egg production and the maturity schedule. We used "high" and "low" estimated annual fecundity that were based on the mean length-specific egg production of each age class, given length-at-age on 1 January, and the minimum and maximum estimated number of annual spawns for each age class. The high annual fecundity scenario assumes more frequent spawning for each individual relative to the low annual fecundity scenario. We also altered the age-specific maturity schedule based on the length-specific maturity relationship we developed. We evaluated the temporal trends in the magnitude of egg production of the stock and the maximum proportion of spawners-per-recruit of the stock for each scenario. We also evaluated the year-specific percent difference in number at age and instantaneous annual fishing mortality $(F)$ at age between the base model used in the 2012 stock assessment and the base model used in the 2013 stock assessment, using the logistic relationship described in this work.

\section{Comparisons of historical data}

To assess historic changes in the Gulf menhaden stock in the northern Gulf of Mexico (Mississippi and Louisiana) we used data $\left(\mathrm{NMFS}^{6}\right)$ obtained from the com-

\footnotetext{
${ }^{6}$ NMFS (National Marine Fisheries Service). 2015. Unpubl. data. Gulf menhaden biostatistical database. [Available from Beaufort Laboratory, Southeast Fish. Sci. Center., Natl. Mar. Fish. Serv., 101 Pivers Island Rd., Beaufort, NC 28516.]
} 
mercial fishery from 1964 to 2014 and archived at the National Marine Fisheries Service (NMFS) Beaufort Laboratory. At each commercial reduction plant operating during these years, a sample of fish was taken from the top of the fish hold. Ten (1971-2014) or 20 (1964-1970) fish were haphazardly selected from that sample. Each fish was weighed (in grams), measured for FL (Schueller et al., 2012), and a scale patch was removed for aging. For fish collected from 1964 to 1970, sex was determined, and gonads were weighed (in grams) and macroscopically classified according to NMFS criteria (Huntsman and Chapoton, 1973). For these data, females were considered reproductively active with a GSI $\geq 1.0$ and males were considered reproductively active with a GSI $\geq 0.5$.

\section{Data analyses}

Reproductive biology Precision of macroscopic in contrast to histological assessment of gender, as well as reproductive phase assessment for both males and females, was compared by calculating percent agreement (Klibansky and Scharf, 2015) and testing with a chi-square test, where differences were considered significant at $P<0.05$. When only 2 phases were compared, the Yates corrected chi-square test was used. The sex ratio was calculated for each month and overall and was analyzed with a chi-square test. The size-at-50\%maturity for males and females was determined with a logistic regression in $\mathrm{R}$ software (vers. 3.1.3; $\mathrm{R}$ Core Team, 2015).

Distribution of males and females in each reproductive phase for each age were compared among months when fish were reproductively active by using the Kolmogorov-Smirnov 2-sample test with a Bonferroni adjustment to determine whether a significant difference existed in reproductive potential among months. Relative batch fecundity ( $\mathrm{RBF}$ ), expressed as number of eggs/g of fish weight, was calculated as BF/ovary-free fish weight. The relationship of $\mathrm{BF}$ and $\mathrm{RBF}$ to fish size (FL, W, age) and $K$ was determined by using linear and nonlinear regression analyses. Data were $\log _{10^{-}}$ transformed where necessary to meet assumptions and provide a better linear fit. Analyses were performed with IBM SPSS Statistics software, vers. 18 (IBM, Armonk, NY) and differences were considered significant if $P<0.05$.

Comparisons of historical data Annual length-weight relationships were determined (1964-2014). Both length and weight were log-transformed and standardized for each year:

$$
\begin{gathered}
g=\frac{(x-\bar{x})}{S D_{\mathrm{x}}} \\
\text { and } h=\frac{(y-\bar{y})}{S D_{\mathrm{y}}},
\end{gathered}
$$

where $x=$ the log-transformed length;

$\bar{x}=$ the mean log-transformed length; and

$$
\begin{aligned}
S D_{\mathrm{x}}= & \text { the standard deviation of } x, y \text { was the log- } \\
& \text { transformed weight; } \\
\bar{y}= & \text { the mean log-transformed weight; and } \\
S D_{\mathrm{y}}= & \text { the standard deviation of } y \text { (Kruschke, 2014). }
\end{aligned}
$$

Standardizing the data was necessary given the correlation between the parameters in the length-weight relationship.

Length-weight relationships were fitted by using Bayesian methods for linear regression in $R$ and the program JAGS (Plummer, 2003):

$$
h=\beta_{0}+\beta_{1} g \text {, }
$$

where length, $g$, was related to weight, $h$, through a slope, $\beta_{1}$, and intercept, $\beta_{0}$.

Priors for the slope and intercept parameters were normally distributed $\mathrm{N}(0,0.1)$. A total of 30,000 chains were run for each year and a 10,000-chain burn-in period.

Comparisons of FL, GSI, and $K$ of reproductively active males and females collected in September and October during 1964-1970 and 2014-2015 were made with $t$-tests; equality of variance was assessed with Levene's test. These analyses were performed with IBM SPSS Statistics software (vers. 18) and considered significant at $P<0.05$.

\section{Results}

\section{Age determination}

Age estimates were determined from scales of 539 Gulf menhaden ( 269 females, 213 males, 57 fish of unknown sex) collected from 2014 through 2015 and used in our analyses of reproductive biology. Age estimates ranged from 1 through 4 years, with the majority of males and females in the age- 2 class. Most fish of unidentified sex were age-1, corresponding to immature or young-ofyear individuals. There was a large overlap in lengthat-age, likely owing to the extended spawning season and variability in length-at-age.

\section{Reproductive biology}

A total of 697 Gulf menhaden were collected from 2014 through 2016 for reproductive analysis, composed of 337 females, 294 males, and 66 fish of unknown sex, of which 22 were $<130 \mathrm{~mm}$ FL and sexually immature. Macroscopic differentiation of gender was particularly difficult for fish that were reproductively inactive or were frozen before analysis. Overall, there was $80 \%$ agreement between macroscopic and histological gender assignment for females and $84 \%$ agreement for males. Chi-square analysis showed a significant misclassification of gender based on macroscopic observations for males and females $\left(\chi_{593}^{2}=239.1, P<0.001\right)$, suggesting histological analysis is necessary to accurately determine gender of Gulf menhaden, particularly with frozen specimens. 
Overall, the sex ratio of Gulf menhaden was not significantly different from 1:1. Females dominated the collections in February, June, September, October, and for all months combined, and significantly more females than males were sampled in September $(P=0.019)$. Relatively equal sex ratios suggested that fish of both sexes are equally susceptible to fishing pressure and there is no difference in mortality associated with gender.

Size at sexual maturity was found to be virtually identical for males and females. Lengthat-50\%-maturity was calculated as $137.2 \mathrm{~mm}$ FL and $140.0 \mathrm{~mm}$ FL for females (Fig. 1A) and males (Fig. 1B), respectively. Fish this size typically recruit into the commercial fishery in the late summer and early fall and were considered to be late age- 1 .

Histological analysis There was poor agreement between macroscopic and histological assessment of reproductive phase for female Gulf menhaden $\left(\chi^{2}{ }_{318}=198.2, P<0.001\right)$. However, the Yates corrected chi-square test for comparison of histological and macroscopic agreement in reproductive assessments of the spawning capable and actively spawning phases showed there was not a significant difference in misclassification between these 2 phases (Yates $\chi^{2}{ }_{72}=3.44, P=0.064$ ). There was also poor agreement between macroscopic and histological assessment of reproductive phase for male Gulf menhaden $\left(\chi^{2}{ }_{275}=137.0, P<0.001\right)$. However, agreement between macroscopic and histological assessments of reproductive phase improved when Gulf menhaden were classified as either reproductively active or inactive. For females, 99\% of fish macroscopically assessed as reproductively inactive remained in that classification after histological inspection and there was an $82 \%$ agreement between macroscopic and histological assessment for reproductively active females. Similarly, males showed a 98\% agreement for reproductively active fish and a $93 \%$ agreement for reproductively inactive fish when macroscopic and histological classifications were compared.

Gulf menhaden ovarian tissue showed asynchronous oocyte development and evidence of batch spawning. Females in the spawning capable phase had oocytes in all stages of development, and there was evidence of POFs in some ovaries in early October (Fig. 2A). Females in the actively spawning subphase (Fig. 2B) had oocytes undergoing OM or hydrated oocytes, as well as vitellogenic oocytes in various stages of development (Fig. 2B). The immature phase was histologically distinguished from the regenerating phase by the smaller size of the primary growth oocytes, lack of space among oocytes, and the large amount of interstitial tissue present in the immature ovary.

The testis of Gulf menhaden is an anastomosing tubular type, characterized by highly branched germi-
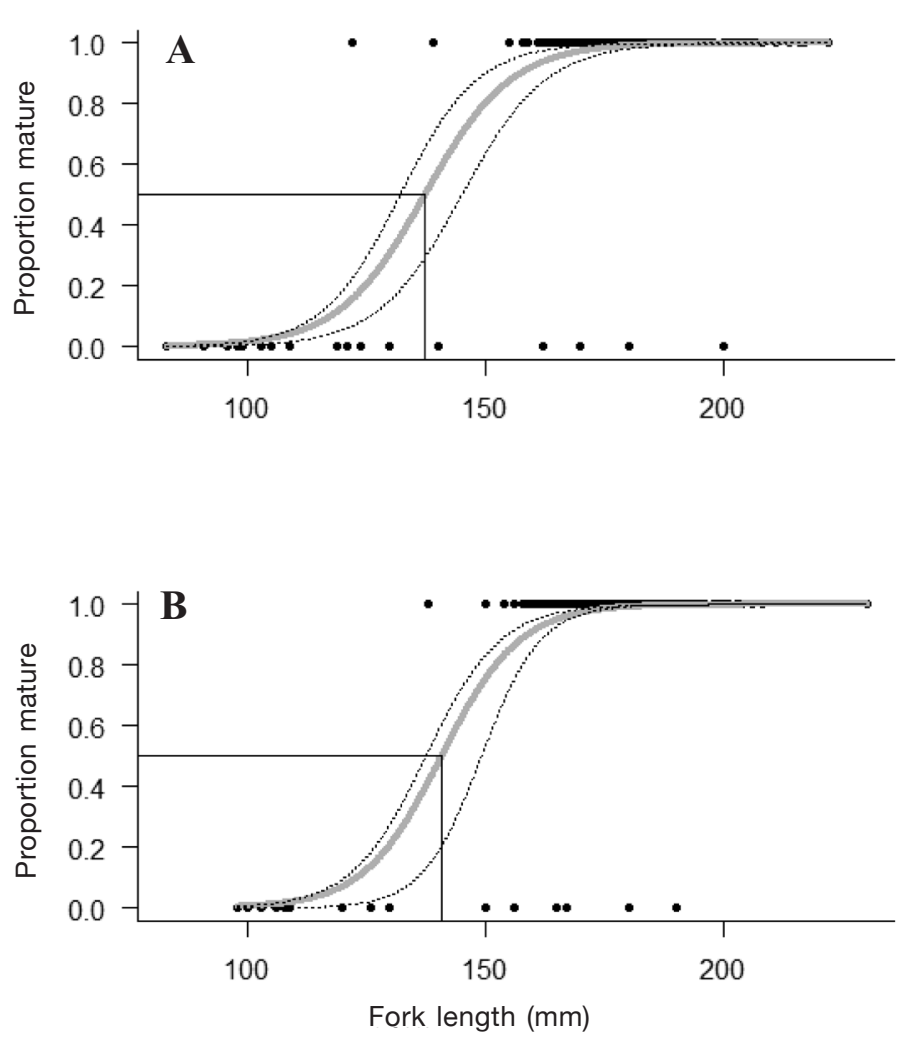

Figure 1

Logistic regression of maturity at size for $(\mathbf{A})$ female and (B) male Gulf menhaden (Brevoortia patronus) collected from the northern Gulf of Mexico during 2014 through 2016. Solid black lines indicate size at $50 \%$ maturity. The gray line is the mean prediction, and the dotted lines are the $95 \%$ confidence intervals.

nal compartments that do not terminate at the testis periphery. Testicular tissue showed differences in the number of spermatocysts along the tubules as the reproductive season progressed. Active spermatogenesis was evident in males in the early germinal epithelium (GE) subphase of the spawning capable phase (Fig. $2 \mathrm{C}$ ), and spermatogonia, spermatocytes and spermatids present within cysts completely lined the tubules; additionally, tubules were filled with spermatozoa. In the late GE subphase, typical of the end of the reproductive period, the tubules were still swollen with spermatozoa, but little active spermatogenesis was taking place, and few spermatocysts were seen lining the tubules (Fig. 2D). The regenerating phase was histologically distinguished from the immature phase in males by the presence of some residual spermatozoa $(\mathrm{Sz})$ within the tubules. Testicular tissue from males collected in September and October showed microspoordian infection, although this was not a common occurrence.

Spawning seasonality The GSI values increased in early October for both males and females, and reached peak values for females by the second half of October (Fig. 3). 


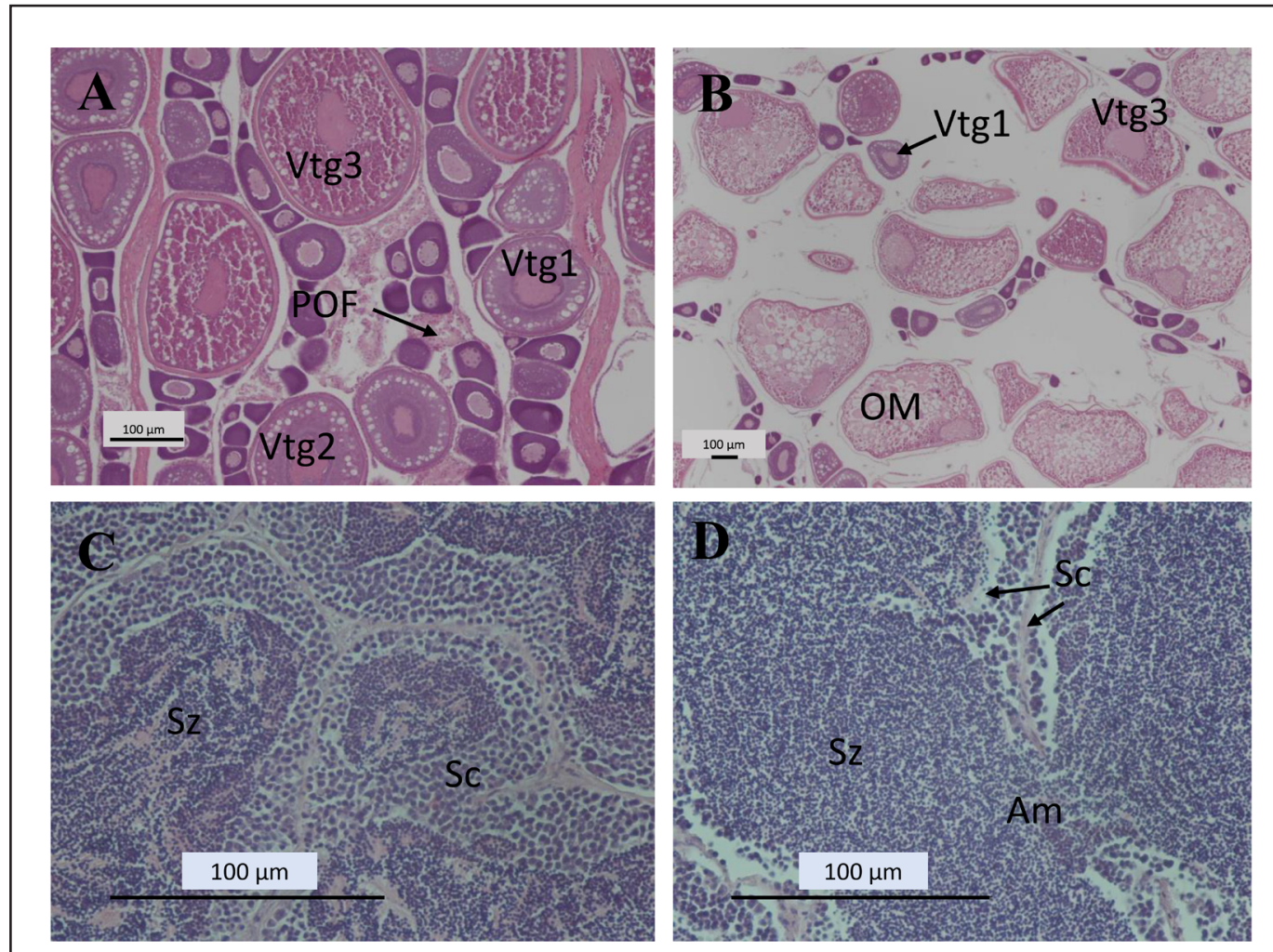

Figure 2

Histological sections of gonadal tissue in the spawning capable phase from Gulf menhaden (Brevoortia patronus) collected from the northern Gulf of Mexico in 2014. (A) Female in spawning capable phase, showing asynchronous oocyte development and evidence of batch spawning (postovulatory follicle [POF] complex); fish captured 6 October 2014. (B) Female in actively spawning sub-phase, showing asynchronous oocyte development and a distinct batch of oocytes in the germinal vesicle migration stage of oocyte maturation $(\mathrm{OM})$, just prior to spawning; fish captured 28 October 2014. (C) Male in early germinal epithelium (GE) sub-phase of spawning capable reproductive phase, with the tubules outlined by a continuous GE undergoing active spermatogenesis; fish captured 6 October 2014. (D) Male in late GE sub-phase of spawning capable reproductive phase (note that spermatocysts are uncommon along tubules as spermatogenesis decreases); fish captured 28 October 2014. Am=anastomosing tubules; $\mathrm{St}=$ spermatid; Sz=spermatozoa; Vtg1=primary vitellogenic oocyte; Vtg2=secondary vitellogenic oocyte; Vtg3=tertiary vitellogenic oocyte.

Female GSI remained elevated but gradually decreased from late October through March, whereas male GSI remained elevated from early October through March and there was no gradual decline during the reproductive season (Fig. 3). Mean male and female GSI values suggest a spawning season extending from early October through the end of March.

Histological analysis allowed refinement of the Gulf menhaden spawning season. All females captured in late August were in the regenerating phase, and females first began to exhibit gonadal recrudescence in mid-September (Table 1A). By early October, $>50 \%$ of females were spawning capable (Table 1A). Histological evidence that Gulf menhaden begin spawning in early October includes the presence of some females in the actively spawning subphase, as well as $22 \%$ of spawn- ing capable females having POF (Fig. 2A). By late October through late February, all sexually mature females captured were spawning capable, with $41 \%$ and $35 \%$ of these actively spawning in October and January, respectively (Table 1A). Although many females were in the regenerating reproductive phase by March (Table 1A), some remained spawning capable in mid-March, and $66 \%$ of those were actively spawning. Thus, histological analysis showed that female Gulf menhaden were actively spawning from early October through mid-March, a 5.5-month spawning season that was similar to that seen in the GSI data (Fig. 3).

Male Gulf menhaden began gonadal recrudescence sooner than females; active spermatogenesis was occurring in $49 \%$ of males captured in late August as they entered the early developing or developing phases 
(Table 1B). By mid-September, some males were in the spawning capable reproductive phase, and $72 \%$ of males were spawning capable by early October (Table 1B). Spawning capable males dominated collections from October through March. Males in the regressing and regenerating phases were first seen in early March, and by mid-April all males had ceased spawning (Table 1B). During the early portion of the spawning season (October and November), most males were found in the early GE (Fig. 2C) subphase of the spawning-capable reproductive phase, indicating active spermatogenesis throughout the testis. Active, although somewhat reduced, spermatogenesis continued during January and February (mid GE subphase). At the end of the spawning season in March, all males were in the late GE subphase (Fig. 2D) and reduced spermatogenesis, but abundant spermatozoa, were still present in the tubules. Histological analysis showed that most males were spawning capable during the same 5.5-month period when females were spawning capable.

Age-based differences in gonadal recrudescence were evident in both females and males at the beginning of the reproductive season. Although there was no significant difference in the distribution of reproductive phases between age- 1 and age- 2 females in September $(P=0.088)$, no age-1 females were in the developing phase (Fig. 4). There was a significant difference between age- 1 and age- 2 females in October $(P=0.047$, Fig. 4$)$, with a much higher percentage of age-1 fish in the immature, early developing, and developing phases compared with age-2 females. There was no difference in distribution across all 3 ages, or between ages- 2 and $-3(P=0.165$ and 0.875 , respectively; Fig. 4) in October. Therefore, younger female Gulf menhaden appeared to have a delayed beginning of the reproductive season.

Age- 1 and age-2 males did not exhibit a significant difference $(P=0.514)$ in the distribution of reproductive phases (Suppl. Fig. 1) in August at the beginning of gonadal recrudescence. However, in September a significant difference $(P=0.017)$ in phase distribution was seen (Suppl. Fig. 1). A high percentage of age-1 males were in the immature and early developing phases and no spawning capable individuals were observed, whereas immature age-2 males were not present in September, a high percentage of age- 2 males were present in the developing phase, and some age- 2 males were spawning capable (Suppl. Fig. 1). Although there was no significant difference in reproductive phase distribution between ages- $1,-2$, and -3 in October $(P=0.056)$, the percentage of males in the developing phase decreased with increasing age, and all age-3 fish captured were spawning capable (Suppl. Fig. 1). Therefore, younger male Gulf menhaden also exhibited a delayed beginning of the reproductive season when compared to older males.

Spawning frequency Spawning frequency varied depending on the method used (Table 2). The OM method provided a more consistent estimation of spawning fre-

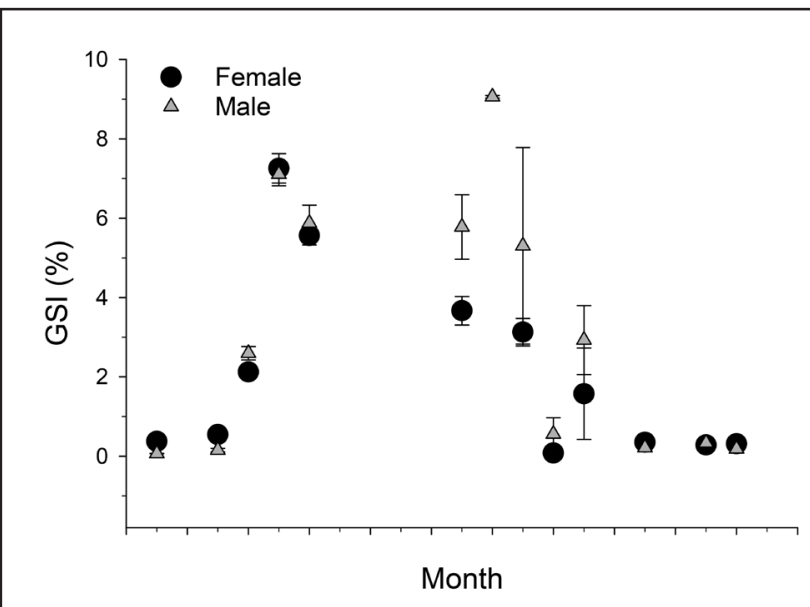

Figure 3

Mean bimonthly gonadosomatic index (GSI) values of male and female Gulf menhaden (Brevoortia patronus) collected from the northern Gulf of Mexico in 2014 through 2016. Error bars indicate standard errors of the means.

quency than the POF method (Table 2) with the exception of the early October sample, when Gulf menhaden were just beginning to spawn. Spawning frequency estimates from February and March should be viewed with caution because of low sample sizes. Combining fish from all months, spawning frequency ranged from every 2.1 to 4.3 days, depending on the method used. Assuming a 5.5-month spawning season, these spawning frequency estimates suggest that an individual female Gulf menhaden has the potential to spawn 38-79 times during the reproductive season. Smaller, age-1 females likely have fewer potential spawns than older, larger females during the reproductive season (35-71 times) because of the delay in reaching the actively spawning subphase in early October (Fig. 4).

Fecundity Samples were analyzed from 16 actively spawning Gulf menhaden from late October through March. Fish ranged in size from 165 to $203 \mathrm{~mm}$ FL and were primarily age 2 . Batch fecundity ranged from 2829 to 59,423 eggs per individual, with an overall mean BF of 15,367 eggs (standard error [SE] 3260; median: 11,577). The RBF ranged from 31.1-328.3 eggs/g ovary-free body weight with an overall mean of 107.8 eggs/g ovary-free body weight (SE 17.1; median: 101.7). Batch fecundity was significantly $\left(F_{1,15}=5.629\right.$, $P=0.033$ ), positively related to $\mathrm{FL}$, although this relationship explained only $28.7 \%$ of the variation in $\mathrm{BF}$ (Fig. 5). Batch fecundity was also significantly positively related to weight $\left(F_{1,15}=5.278, P=0.038\right.$, coefficient of determination $\left.\left[r^{2}\right]=0.274\right) . \log _{10}$ transformation of the data resulted in the best predictive fit for $B F$ and FL; the predictive equation was:

$$
\log B F=4.695(\log \mathrm{FL})-6.547 \text {. }
$$




\begin{tabular}{|c|c|c|c|c|c|c|c|c|c|c|}
\hline \multicolumn{11}{|c|}{ Table 1} \\
\hline \multicolumn{11}{|c|}{$\begin{array}{l}\text { Bimonthly percentages of (A) female and (B) male Gulf menhaden (Brevoortia patronus), collected from } \\
\text { Mississippi and Louisiana coastal waters of the northern Gulf of Mexico during 2014-2016, in re- } \\
\text { productive phases determined by histological examination. The phases include immature (Imm), early } \\
\text { developing subphase (EDev), developing (Dev), spawning capable (SC), early germinal epithelium (GE) } \\
\text { subphase (EGE), mid GE subphase (MGE), late GE subphase (LGE), actively spawning subphase (AS), } \\
\text { regressing (Rgs), and regenerating (Rgn). }\end{array}$} \\
\hline \multicolumn{11}{|c|}{ (A) Females } \\
\hline Date & $n$ & $\mathrm{Imm}$ & & & Dev & $\mathrm{SC}$ & A & & Rgs & Rgn \\
\hline 16-31 Aug & 46 & 0 & & & 0 & 0 & & & 0 & 100 \\
\hline 16-30 Sep & 80 & 5 & & & 3 & 0 & & & 0 & 86 \\
\hline $1-15$ Oct & 56 & 2 & & & 20 & 57 & & & 0 & 7 \\
\hline 16-31 Oct & 64 & 1 & & & 0 & 58 & & & 0 & 0 \\
\hline 1-15 Nov & 14 & 0 & & & 0 & 100 & & & 0 & 0 \\
\hline 16-31 Jan & 17 & 0 & & & 0 & 59 & & & 0 & 0 \\
\hline 1-15 Feb & 4 & 100 & & & 0 & 0 & & & 0 & 0 \\
\hline 16-28 Feb & 6 & 0 & & & 0 & 100 & & & 0 & 0 \\
\hline 1-15 Mar & 1 & 0 & & & 0 & 0 & & & 100 & 100 \\
\hline 16-31 Mar & 7 & 14 & & & 0 & 14 & & & 0 & 43 \\
\hline 16-30 Apr & 5 & 0 & & & 0 & 0 & & & 0 & 100 \\
\hline 1-15 May & 15 & 7 & & & 0 & 0 & & & 0 & 93 \\
\hline 1-15 Jun & 23 & 4 & & & 0 & 0 & & & 0 & 96 \\
\hline \multicolumn{11}{|l|}{ (B) Males } \\
\hline \multirow[b]{2}{*}{ Date } & & & & & & \multicolumn{3}{|c|}{ SC subphase } & \multirow[b]{2}{*}{ Rgs } & \multirow[b]{2}{*}{ Rgn } \\
\hline & $n$ & $\mathrm{Imm}$ & EDev & Dev & $\mathrm{SC}$ & EGE & MGE & LGE & & \\
\hline 16-31 Aug & 50 & 4 & 41 & 8 & 0 & 0 & 0 & 0 & 0 & 47 \\
\hline $16-30 \mathrm{Sep}$ & 54 & 6 & 37 & 36 & 4 & 0 & 0 & 0 & 0 & 17 \\
\hline $1-15$ Oct & 50 & 0 & 0 & 28 & 72 & 83 & 17 & 0 & 0 & 0 \\
\hline 16-31 Oct & 56 & 0 & 0 & 0 & 100 & 59 & 37 & 4 & 0 & 0 \\
\hline $1-15$ Nov & 14 & 0 & 0 & 0 & 100 & 60 & 30 & 10 & 0 & 0 \\
\hline 16-31 Jan & 16 & 0 & 6 & 0 & 94 & 31 & 69 & 0 & 0 & 0 \\
\hline $1-15 \mathrm{Feb}$ & 3 & 0 & 0 & 0 & 100 & 0 & 100 & 0 & 0 & 0 \\
\hline $16-28$ Feb & 2 & 0 & 0 & 0 & 100 & 0 & 0 & 0 & 0 & 0 \\
\hline 1-15 Mar & 4 & 0 & 25 & 0 & 25 & 0 & 0 & 100 & 25 & 25 \\
\hline 16-31 Mar & 4 & 0 & 0 & 0 & 75 & 0 & 0 & 100 & 25 & 0 \\
\hline 16-30 Apr & 12 & 0 & 0 & 0 & 0 & 0 & 0 & 0 & 33 & 67 \\
\hline 1-15 May & 16 & 6 & 6 & 0 & 0 & 0 & 0 & 0 & 6 & 82 \\
\hline 1-15 Jun & 13 & 0 & 8 & 0 & 0 & 0 & 0 & 0 & 15 & 77 \\
\hline
\end{tabular}

Batch fecundity was not significantly related to age $(P=0.698)$ nor $K(P=0.768)$. Additionally, RBF was not significantly related to length $(P=0.282)$, weight $(P=0.615)$, or $K(P=0.546)$, suggesting the RBF calculation removes the effects of fish size and can therefore be used to accurately compare fecundity of differentsize fishes. Thus, based on RBF and spawning frequency, an average size female of $150 \mathrm{~g}$ may produce as many as 614,460-1,277,430 eggs during the 5.5-month reproductive season.

The oocyte dynamics of Gulf menhaden offer an unclear picture as to whether this species has determinate or indeterminate fecundity. Oocyte size-frequency distributions of secondary growth oocytes in Gulf menhaden from October and March show a dramatic re- duction in the number of small vitellogenic oocytes in March than in October (Fig. 6), suggesting that new oocytes are not recruited into vitellogenesis at the end of the spawning season-a pattern typical of determinate fecundity but also seen in some species with indeterminate fecundity. The gap in oocyte distribution between primary and secondary growth oocytes typically seen in species with determinate fecundity is not seen in Gulf menhaden, although that is not unexpected in this instance because only secondary growth oocytes were counted. Histological observations of females from February and March showed a lower percentage of primary and secondary vitellogenic oocytes in the ovary than from October and November, suggestive of determinate fecundity. However, the percentage of atresia in 


\section{Table 2}

Estimates of spawning frequency of spawning capable Gulf menhaden (Brevoortia patronus) collected from Mississippi and Louisiana coastal waters during 2014 through 2016. Estimates were derived by using 2 different calculation methods: postovulatory follicle $(\mathrm{POF})$ and oocyte maturation $(\mathrm{OM})$, including hydrated oocytes.

\begin{tabular}{lrcc}
\hline Month & $n$ & POF method & OM method \\
\hline Early October & 32 & $22 \%, 4.5$ days & $6.25 \%, 16$ days \\
Late October & 63 & $6.3 \%, 15.9$ days & $41.3 \%, 2.4$ days \\
All October & 95 & $4.6 \%, 8.6$ days & $29.5 \%, 3.4$ days \\
Early November & 14 & $21 \%, 4.76$ days & $0.0 \%$ \\
Late January & 16 & $43.8 \%, 2.3$ days & $37.5 \%, 2.6$ days \\
Late February & 6 & $83 \%, 1.2$ days & $0.0 \%$ \\
Late March & 3 & 0 & $66.6 \%, 1.5$ days \\
All combined & 134 & $23.1 \%, 4.3$ days & $47.8 \%, 2.1$ days \\
& & &
\end{tabular}

females in the regressing reproductive phase ranged from 2.3 to $13.9 \%$; atresia percentages $>10 \%$ are suggestive of indeterminate fecundity. Similarly, calculations of total annual fecundity present conflicting evidence of determinate or indeterminate fecundity. Total fecundity of a 181-g female was 473,370 eggs, based on total oocytes at the beginning of the season but 1,658,316 eggs based on $\mathrm{BF}$ and spawning frequency (suggestive of indeterminate fecundity), whereas total fecundity of a 132-g female was 204,347 eggs based on total oocytes at the beginning of the season and 174,958 eggs based on $\mathrm{BF}$ and spawning frequency (suggestive of determinate fecundity). Finally, although a steady decrease in GSI values as the season progresses (Fig. 3) is typical of species with determinate fecundity, this decrease can also occur in species with indeterminate fecundi-
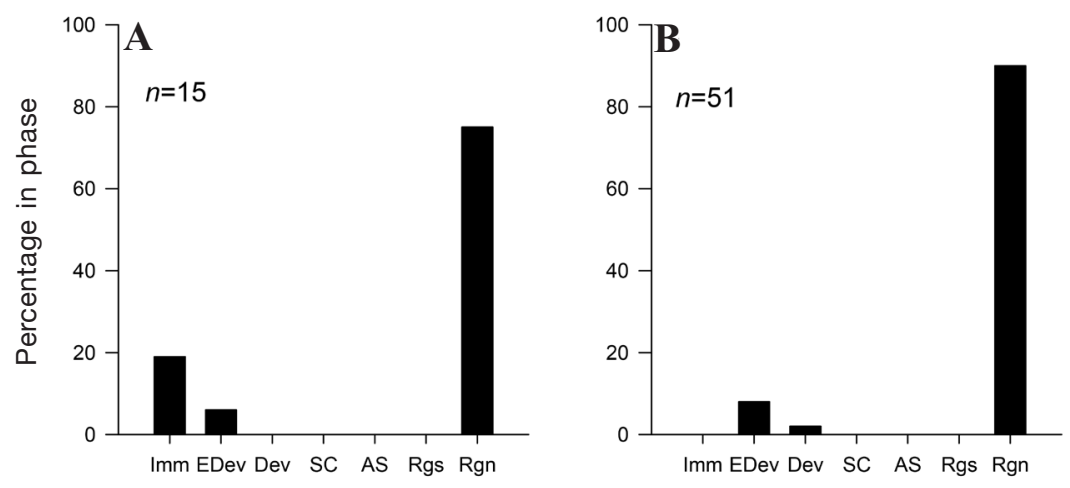

Age 1 and 2 in September: $P=0.088$

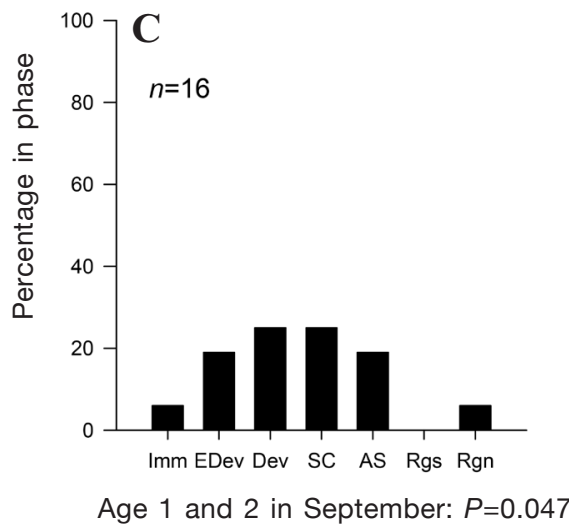

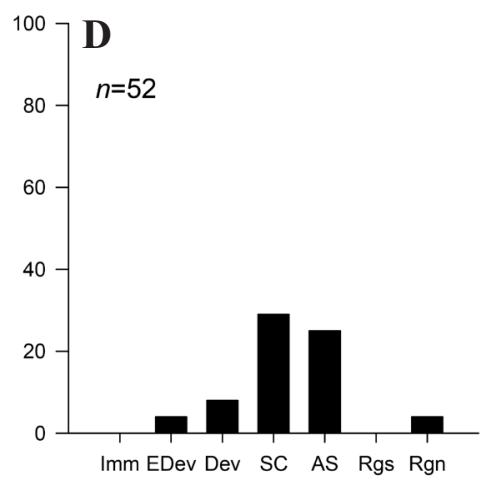

Ages 1,2 and 3 in October: $P=0.165$

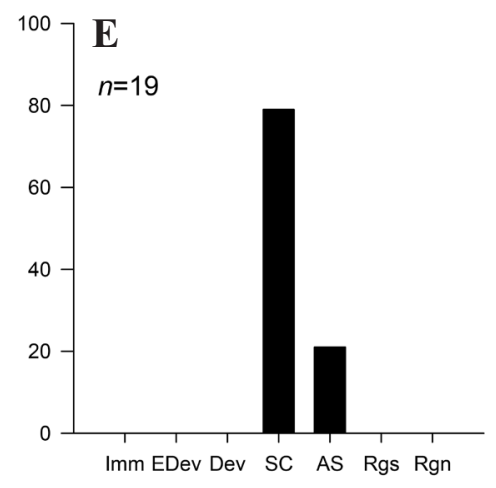

Age 2 and 3 in October: $P=0.875$

Figure 4

Distribution of female reproductive phases for Gulf menhaden (Brevoortia patronus) collected from the northern Gulf of Mexico during 2014 through 2016, by age at the beginning of the reproductive season: (A) age-1 and (B) age-2 females in September and $(\mathbf{C})$ age-1, $(\mathbf{D})$ age-2, and (E) age-3 females in October. The probabilities $(P)$ from the results of a KruskallWallace 2-sample test of similarity of distributions within a month are provided. The reproductive phases are immature (Imm), early developing (EDev), developing (Dev), spawning capable (SC), actively spawning (AS), regressing (Rgs), and regenerating (Rgn). 


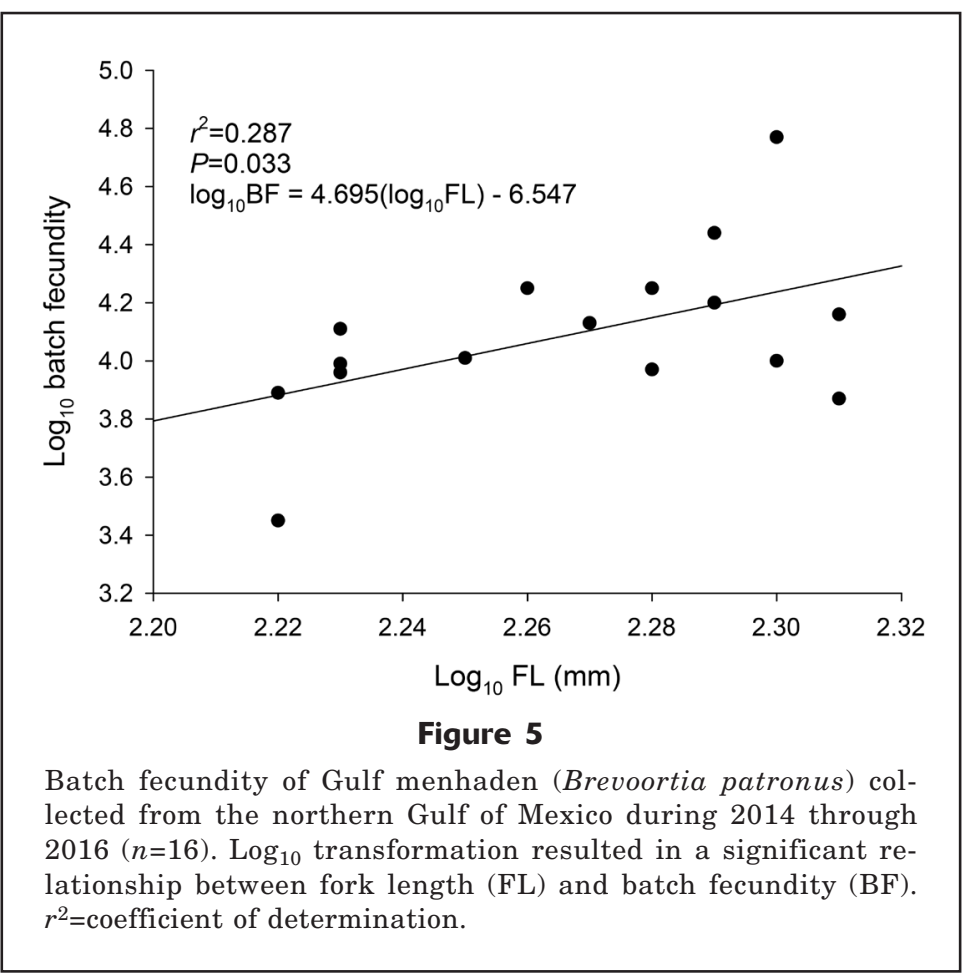

$F$ in age classes $0,2,3$, and 4 of $\sim 1.5 \%$ and an increase in the estimated $F$ rate for age- 1 of $<0.5 \%$ (Suppl. Fig. 2B). Estimated selectivity of age- 1 fish in the commercial reduction fishery for the updated fecundity estimates was marginally greater than that estimated in the base model formulation (0.050 vs. 0.051). Estimated log-transformed catchability of the 2 fishery-independent gears (gill and seine nets) used to sample the stock exhibited minor differences in the base model formulation (1.251 and 1.177 for the high and low estimates, respectively). Catchability of the seine gear was reduced from 0.127 to 0.125 .

\section{Comparisons of historical data}

Annual sample sizes from the Gulf menhaden fishery during 1964 through 2014 ranged from 4611 in 2010 to 16,823 fish in 1994 (Suppl. Table). Low sample size in 2010 was the result of closures of fishing areas due to the Deepwater Horizon oil spill. Mean estimated slope and intercept for the length-weight relationships varied over time (Suppl. Fig. 3). The highest slope was 3.98 in 1991 and the lowest slope was 2.52 in 1986. Slope translates into how ty and an extended spawning season. These conflicting lines of evidence lead us to conclude that Gulf menhaden likely have indeterminate fecundity, but also show some characteristics of determinate fecundity.

\section{Modeling stock assessments}

The incorporation of "high" estimates of annual fecundity (based on age-1 with 71 spawnings/year and age$2+$ with 79 spawnings/year), "low" estimates of annual fecundity (based on age-1 with 35 spawnings/year and age-2+ with 38 spawns/year), and alternative maturity schedules affected stock-level estimates. Altering the fecundity estimate in the high and low scenarios increased estimated annual egg production 100- to 1000fold for each year of the assessment model (Fig. 7A). Altering the maturity schedule to include age- 1 reproduction ( $68 \%$ of age- 1 individuals capable of spawning) resulted in an approximately 10 -fold increase in stocklevel egg production for each fecundity scenario (Fig. 7A) but reduced the proportion of maximum spawning per recruit in each of the scenarios (Fig. 7B). The percent change in estimated numbers-at-age between the scenarios that included age-1 reproduction and base model estimates indicated that there was a greater number of individuals in each age class for all years examined, particularly in the age-3 and age-4+ groups (Suppl. Fig. 2A). In 2012, the estimated percent decrease in number at age was small for the age classes 1 and $2(<1 \%)$ but was reduced $9.3 \%, 4.2 \%$ and $9.8 \%$ for ages-0, 3 and 4 , respectively. The estimated increase in annual $F$ was small and generally consistent across age classes for each year, with an observed increase in heavy a fish is compared with its length. Slopes of 3.0 indicate a proportional fish; slopes $<3.0$ indicate a skinnier fish and slopes $>3.0$ indicate a heavier fish. Intercept values varied between -15.92 in 1991 to -8.39 in 1986. Variability in the slope and intercept values was generally random, but there were 2 time periods (late 1980 s and late 2000s) that had about 5 years of lower than average slope, therefore indicating Gulf menhaden were less robust during those times.

We found significant differences in reproductionrelated measures in both males and females between 1964-1970 and 2014. Reproductively active females in October 2014 were significantly larger $\left(t_{146}=2.22\right.$, $P=0.03)$, had a higher $K\left(t_{146}=2.708, P=0.008\right)$, and a greater GSI $\left(t_{146}=4.143, P<0.001\right)$ than those from 1964 through 1970 (Table 3). However, no significant difference existed between years in September for any of these measures. Reproductively active males in October 2014 showed significantly greater FL $\left(t_{108}=2.387\right.$, $P=0.019)$ and GSI $\left(t_{108}=2.319, P=0.047\right)$ than those from 1964 through 1970 (Table 3); whereas no significant difference in male condition was found in October, fish from 2014 had higher $K$ than those from 1964 through 1970.

\section{Discussion}

Gulf menhaden continues to be one of the most ecologically and economically important stocks in the northern GOM and plays an important role in the trophic structure of the region (Sagarese et al., 2016). We provide new reproductive information and document 

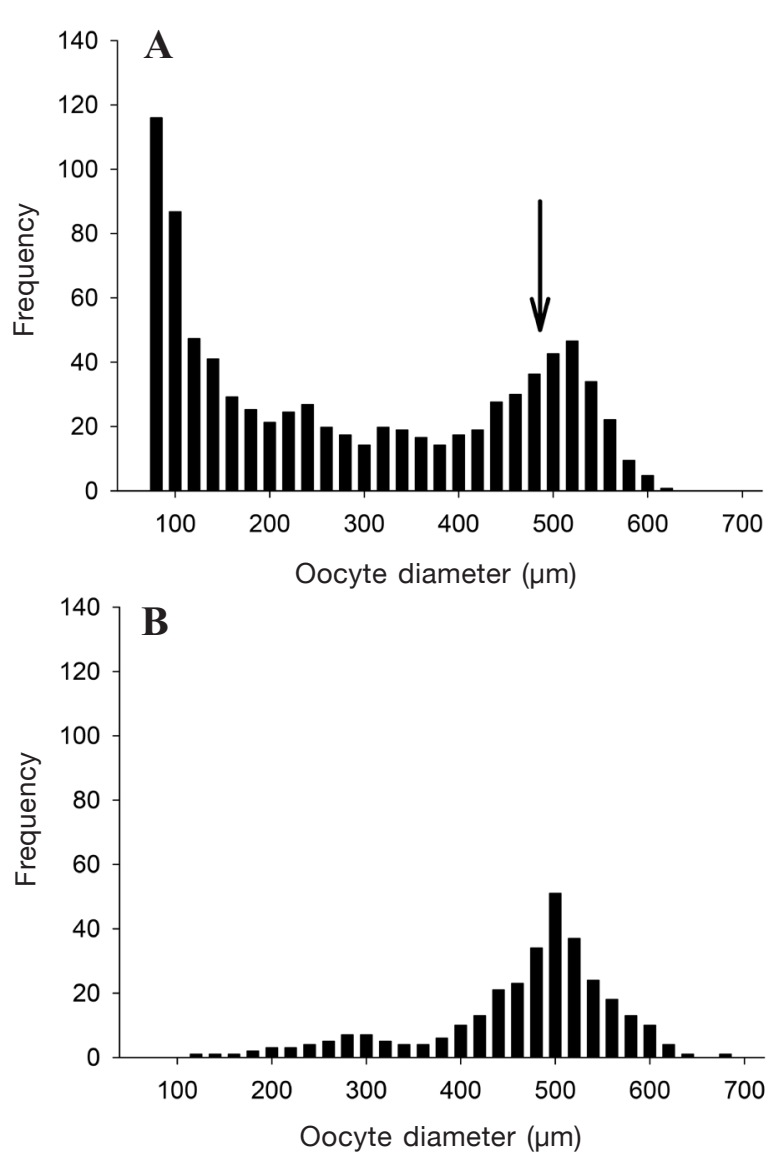

Figure 6

Distributions of oocyte sizes of female Gulf menhaden (Brevoortia patronus) collected from the northern Gulf of Mexico during 2014 through 2016, showing an indeterminate fecundity pattern with lack of recruitment of secondary vitellogenic oocytes at the end of the spawning season. (A) Fish captured 31 October 2014, $186 \mathrm{~mm}$ FL. Arrow indicates oocytes undergoing oocyte maturation; only oocytes $\geq 500 \mu \mathrm{m}$ were counted for fecundity estimates. (B) Fish captured 18 March 2015, $165 \mathrm{~mm}$ FL. Note lack of vitellogenic oocytes from 80 to $350 \mu \mathrm{m}$ in the March sample.

how these new data address critical needs for stock assessments and for understanding the ecological dynamics of the stock. The results of our work indicate that Gulf menhaden have greater fecundity than that previously reported, and the characteristics of the reproductive dynamics are different than previously thought. Specifically, we found that egg production is greater and that the reproductive season is protracted, lasting 5.5-months. We also found that Gulf menhaden are batch spawners that spawn every 2.1-4.3 days and that although they show indeterminate fecundity, they have several traits typically associated with determinate fecundity.

The 5.5-month reproductive season (October-March) for Gulf menhaden from the north-central GOM described here is slightly longer than that previously reported. Combs (1969) found the spawning season occurred from late October to February or early March according to histological analysis, whereas Lewis and Roithmayr (1981) found peak spawning, determined from GSI, to occur from November through January, and that a few spawning capable females were present in February and none after that time. Not only is the Gulf menhaden spawning season longer than previously reported, our data indicate that a high percentage of fish are spawning in October, and these fish are vulnerable to capture by the commercial purse-seine fishery that operates through the end of October.

Smaller and younger Gulf menhaden have a shorter reproductive season than older, larger fish. Although data were not previously available for size-at-sexualmaturity for Gulf menhaden, sexual maturity was assumed to have been reached when fish approach their second birth date (VanderKooy and Smith ${ }^{1}$ ). Indeed, we found that $50 \%$ maturity is reached at $137-140 \mathrm{~mm} \mathrm{FL}$, and fish of this size are found in the fall as they approach their second birth date. However, smaller age-1 fish in the fall have lower GSI values and delayed gonadal development than those of larger fish. Furthermore, our analysis of historic Gulf menhaden data suggests that the reproductive season may have shifted to a slightly earlier start in 2014 than during 1964-1970, possibly as a result of 2014 fish being slightly larger and in better condition. It is well established that older, larger females begin spawning earlier in the reproductive season and that smaller individuals may have a longer time between spawning events than larger individuals of the same species (Lowerre-Barbieri et al., 2011; Fitzhugh et al., 2012). These variations among different-size fish must be taken into account when calculating annual fecundity estimates and estimating spawning stock biomass. Our analysis has taken this variation into account by including a 1-month delay in the spawning season for age-1 fish, although we have insufficient data to estimate differences in spawning frequency between females age- 1 and older.

This study is the first to examine GSI and histology of male Gulf menhaden. Males began gonadal recrudescence about 1 month before females do but, like females, were reproductively inactive by mid-April. Male Gulf menhaden exhibit an anastomosing tubular type of testes typical of other clupeids (Grier and Uribe Aranzábal, 2009). Male and female GSI values were similar in Gulf menhaden, particularly at the beginning of the spawning season, as also seen in another clupeid, the Pacific sardine (Sardinops sagax [Stewart et al. ${ }^{7}$ ). In contrast, some male sardines have higher GSI values than females (Tsikliras and Antonopoulou, 2006; Tsikliras et al., 2010), although male marine te-

\footnotetext{
${ }^{7}$ Stewart, J., G. Ballinger, and D. Ferrell. 2010. Review of the biology and fishery for Australian sardines (Sardinops sagax) in New South Wales-2010. Industry \& Investment NSW, Fish. Res. Rep. Ser. 26, 57 p. [Available from website.]
} 

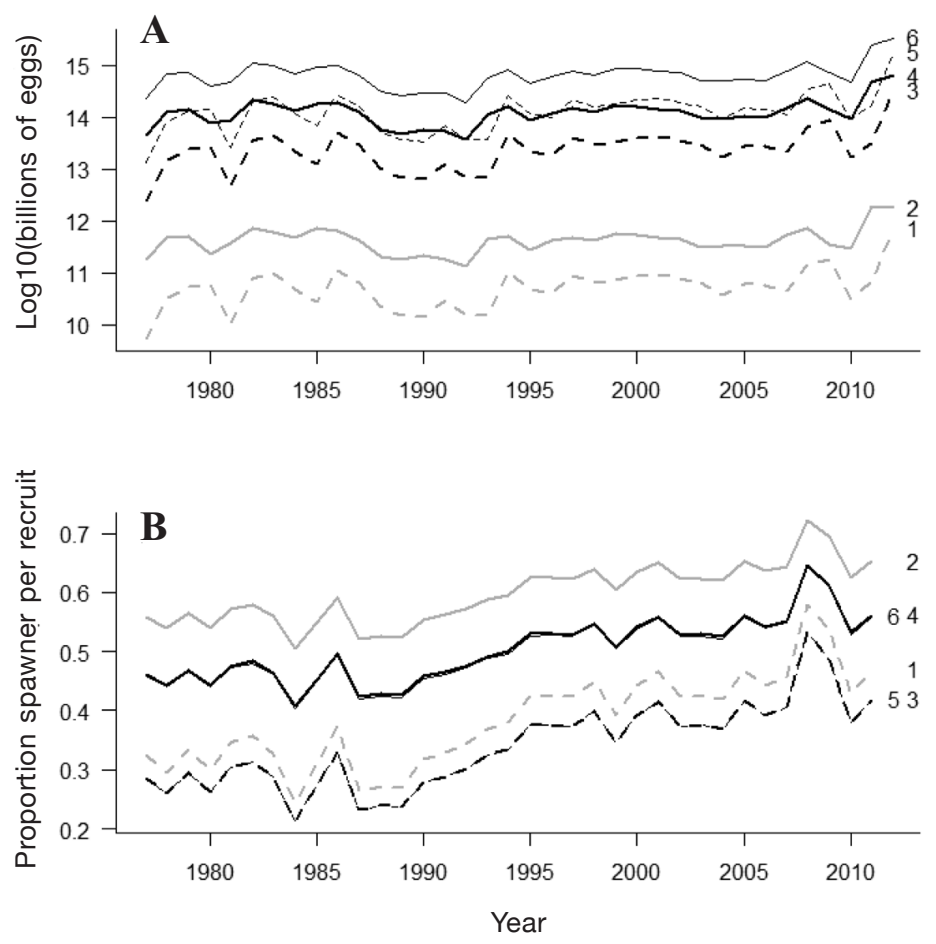

Figure 7

Estimates of (A) annual egg production of the stock and (B) the maximum proportion of spawners-per-recruit of Gulf menhaden (Brevoortia patronus) based on collections from the northern Gulf of Mexico during 2014 through 2016. For each panel, fecundity from Lewis and Roithmayr (1981, lines 1 and 2) and the low (lines 3 and 4) and high (lines 5 and 6 ) estimates of fecundity derived in this study are displayed with 2 different age-specific maturity patterns (dashed and solid lines). Lines 1, 3, and 5 display the expected temporal patterns when the age at first maturity is 2 years. Lines 2 , 4 , and 6 display the expected temporal pattern in maximum proportion of spawners-per-recruit when maturity is modeled with the logistic relationship described in this work (proportion of age-1 spawners is 0.68).

determine reproductive seasonality of Gulf menhaden.

The fecundity pattern of Gulf menhaden has not previously been reported, although Combs (1969) documented asynchronous oocyte development and suggested Gulf menhaden are batch spawners. Fish with determinate fecundity recruit all oocytes to be spawned during the year into vitellogenesis at the beginning of the reproductive season before the first spawing and can be either batch or total spawners, whereas fish with indeterminate fecundity continually recruit oocytes into vitellogenesis throughout the reproductive season and are batch spawners (Murua and Saborido-Rey, 2003). Marine clupeids exhibit both types of fecundity patterns; cold water species, such as Atlantic and Pacific herring (Clupea harengus and C. pallasii), show determinate fecundity and total spawning, whereas many temperate and subtropical batch spawning clupeids (such as species of Sardinella and Sardinops) tend to have indeterminate fecundity (Ganias, 2013). However, American shad (Alosa sapidissima) have recently been shown to have determinate fecundity in northern populations and indeterminate fecundity in southern populations (McBride et al., 2016), as predicted for species with wide geographic ranges by Ganias et al. (2015). The subtropical/tropical clupeid Spanish sardine (Sardinella aurita) has been shown to have determinate fecundity but is likely to be a batch spawner (Tsikliras and Antonopoulou, 2006) while the Brazilian menhaden (Brevoortia aurea) is a batch spawner reported to have indeterminate fecundity (Macchi and Acha, 2000; Lajud et al., 2016). Our data indicate that Gulf menhaden are likely to have indeterminate fecundity, but have some traits more typical of fish with determinate fecundity, such as high GSI val-

leosts typically have notably lower GSI values than females (Wootton, 1998). The high male GSI values of Gulf menhaden and other clupeids may be related to increased sperm competition in the pelagic environment (Stockley et al., 1997), which is common with species that spawn in groups (Erisman and Allen, 2006) such as Gulf menhaden.

Lack of concordance between macroscopic and histological assessment of reproductive phase in Gulf menhaden was unexpected. Although histological assessment remains the best method to accurately identify specific reproductive phases (West, 1990; Brown-Peterson et al., 2011), we found that broadly assessing fish as reproductively active or inactive by macroscopic inspection is sufficiently accurate, as did Klibansky and Scharf (2015). Thus, macroscopic assessments could allow biologists, managers, and industry personnel to ues at the beginning of the spawning season, a reduction in secondary growth oocytes as the spawning season progresses, and the lack of massive atresia at the end of the spawning period in at least some individuals. Indeed, Ganias et al. (2017) showed that some species with indeterminate fecundity can cease recruiting new oocytes during the spawning season; this is likely the case for Gulf menhaden. The variations in fecundity patterns among clupeids show the importance of assessing determinate or indeterminate fecundity for each species and of not relying solely on geographic location or spawning strategy. Understanding fecundity patterns, as well as spawning dynamics, is also important for estimating total annual fecundity.

Our mean BF estimates of 15,367 eggs (SE 3260) are much lower than the previous fecundity estimates for age-2 Gulf menhaden of 47,900 eggs (SE 5038) 


\section{Table 3}

Comparisons of historic and current mean fork length (FL), in millimeters, mean condition $(K)$, and mean gonadosomatic index (GSI) with standard errors (SEs) in parentheses, of reproductively active male and female Gulf menhaden (Brevoortia patronus) collected from the northern Gulf of Mexico at the beginning of the reproductive season. Historic data are for 1964 through 1970; current data are from 2014. Reproductively active fish are defined as GSI $\geq 1.0$ for females and $\geq 0.5$ for males. Significant differences are in bold.

\begin{tabular}{|c|c|c|c|c|c|c|}
\hline & Month & Date & $n$ & $\mathrm{FL}(\mathrm{SE})$ & $t$-value & $P$ \\
\hline \multicolumn{7}{|l|}{ Fork length } \\
\hline \multirow[t]{4}{*}{ Female } & September & Current & 2 & $202.0(9.0)$ & -1.93 & 0.086 \\
\hline & & Historic & 9 & $217.3(3.3)$ & & \\
\hline & October & Current & 105 & $192.0(1.17)$ & 2.22 & 0.03 \\
\hline & & Historic & 43 & $184.9(3.0)$ & & \\
\hline \multirow[t]{2}{*}{ Male } & October & Current & 103 & $185.9(1.1)$ & 2.38 & 0.019 \\
\hline & & Historic & 7 & $175.7(4.8)$ & & \\
\hline \multicolumn{7}{|l|}{ Condition } \\
\hline \multirow[t]{4}{*}{ Female } & September & Current & 2 & $2.098(0.086)$ & 0.197 & 0.848 \\
\hline & & Historic & 9 & $2.069(0.064)$ & & \\
\hline & October & Current & 105 & $2.094(0.027)$ & 2.708 & 0.008 \\
\hline & & Historic & 43 & $2.073(0.022)$ & & \\
\hline \multirow[t]{2}{*}{ Male } & October & Current & 103 & $2.156(0.013)$ & 1.620 & 0.108 \\
\hline & & Historic & 7 & $2.070(0.054)$ & & \\
\hline \multicolumn{7}{|c|}{ Gonadosomatic index } \\
\hline \multirow[t]{4}{*}{ Female } & September & Current & 2 & $1.63(0.59)$ & -0.348 & 0.726 \\
\hline & & Historic & 9 & $2.02(0.50)$ & & \\
\hline & October & Current & 105 & $5.44(0.32)$ & 4.143 & $<0.001$ \\
\hline & & Historic & 43 & $3.75(0.25)$ & & \\
\hline \multirow[t]{2}{*}{ Male } & October & Current & 103 & $5.12(0.28)$ & 2.319 & 0.047 \\
\hline & & Historic & 7 & $3.53(0.63)$ & & \\
\hline
\end{tabular}

(Lewis and Roithmayr, 1981), and the low $r^{2}$ value for the fecundity-size relationship is typical among batch spawning fish species. We counted only oocytes $\geq 500$ $\mu \mathrm{m}$ for fecundity estimates-sizes that correspond to oocytes about to be spawned (i.e., hydrated oocytes or oocytes undergoing OM), whereas Lewis and Roithmayr (1981) counted all oocytes $>360 \mu \mathrm{m}$, which included vitellogenic oocytes that would not be released in a batch. Although there are no previous estimates of $\mathrm{RBF}$ for Gulf menhaden for comparison purposes, Lajud et al. (2016) reported RBF ranged from 50-381 eggs/g ovary-free body weight in the Brazilian menhaden, within the RBF range of 60-212 eggs/g ovary-free body weight previously reported by Macchi and Acha (2000) for the same species; both values are similar to our estimates of 31-328 eggs/g ovary-free body weight for Gulf menhaden.

Despite the lower estimate of $\mathrm{BF}$ presented here, the total annual estimated fecundity is 11-23 times greater than the values provided by Lewis and Roithmayr (1981) for fish of all sizes (Fig. 8) as a result of combining $\mathrm{BF}$ estimates with spawning frequency estimates. The methods we used to determine spawning frequency could result in either underestimation of spawning frequency (due to degradation or destruction of POF due to sample treatment) or an overestimation (due to congregation of females undergoing OM in the sampled area), and for this reason we provide a high and low range which results in a more accurate estimation of total annual fecundity than that of previous reports. Our spawning frequency estimates are higher than those of the only other report of spawning frequency for a species of menhaden (Brazilian menhaden, every 8 days [Macchi and Acha, 2000]). Gulf menhaden appear to spawn more frequently than European pilchard (Sardina pilchardus, every 11-12 days) and Pacific sardine (every 10 days)_batch spawning clupeids with indeterminate fecundity and group synchronous oocyte development (Ganias et al., 2004; Lo et al., 2010). However, Brazilian sardinella (Sardinella brasiliensis) spawn as frequently as every 2 days during the peak spawning season (Isaac-Nahum et al., 1988) - a frequency that is similar to ours for Gulf menhaden.

Estimates produced from the re-analysis of the stock assessment indicate that some model output, including the number-at-age, age-specific fishing mortality, and spawners-per-recruit are sensitive to alterations in age-specific annual fecundity. A primary use for determining length- and age-specific fecundity is for inclusion in assessment models for determination of 


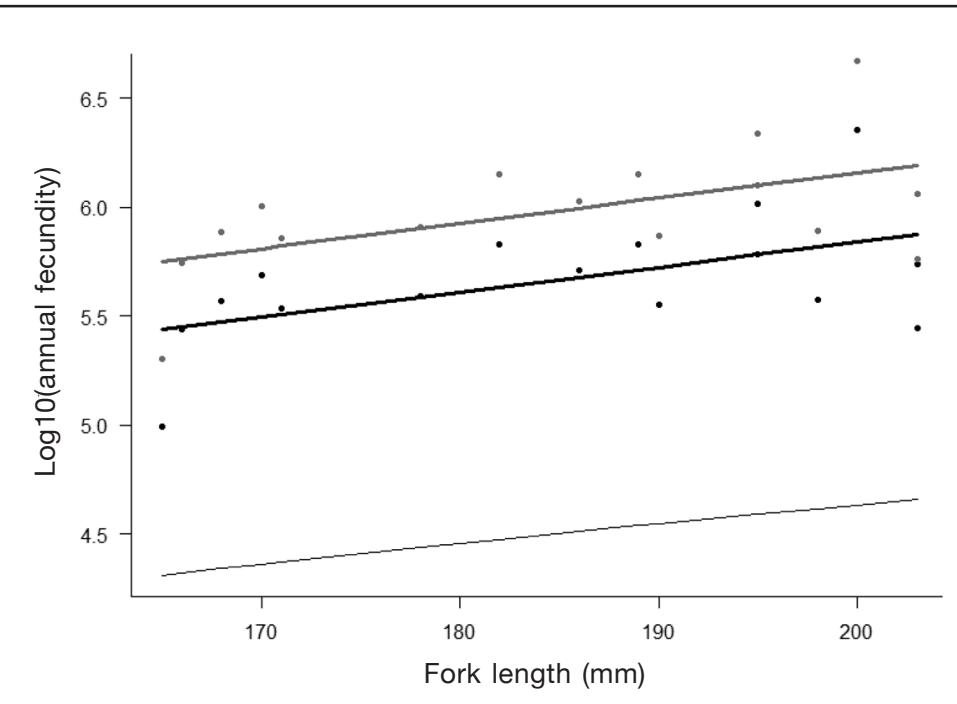

Figure 8

Fork length in relation to specific annual fecundity of Gulf menhaden (Brevoortia patronus) collected from the northern Gulf of Mexico during 2014 through 2016. Thick lines are fitted to gray (high estimate, spawning frequency of 2.1 days) and black (low estimate, spawning frequency 4.3 days) points. The thin line is the lengthspecific fecundity estimate from Lewis and Roithmayr (1981).

Thus, the new data provided here suggests that the dramatically greater estimated reproductive output of Gulf menhaden not only has potentially positive impacts at the ecosystem level, but also helps explain a continued robust Gulf menhaden stock despite high fishing pressure.

\section{Acknowledgments}

We thank K. Herbert (Omega Protein), T. Bui (Louisiana Cooperative Extension Service), C. Dean (Louisiana Department of Wildlife and Fisheries), and W. Dempster (USM CFRD) for assistance in obtaining Gulf menhaden, C. Jones (USM) for data collection, E. Hall and J. Potts (NMFS Beaufort Laboratory) for providing ages, and J. W. Smith (NMFS Beaufort Laboratory) for project facilitation and oversight. This research was funded by Cooperative Research Program grant \#NA14NMF4540064 from the NMFS to the senior author and R. Leaf.

\section{Literature cited}

stock status. Our results indicate that even in the face of the intense fishing pressure during the early and mid-1980s, the proportion of spawners-per-recruit has remained near $30 \%$ or less for the duration of the assessment history. Selectivity and catchability parameters changed only a small amount. The small reduction in the estimated catchability parameters for each gear followed the estimated increases for numbers-at-age observed throughout the time series.

Overall, the condition of the Gulf menhaden stock has remained relatively constant over the past 50 years despite heavy fishing pressure because the $95 \%$ Bayesian credible intervals of the historical lengthweight relationships generally encompass the constant slope and intercept values from Schueller et al. (2012). Although growth has been variable over time, the data indicate that there has not been a directional change in growth with harvest pressure over time. The stock seems to be resilient to changes in harvest pressuresa feature that adds to its sustainability (Schueller ${ }^{3}$ ).

We note that the effects on the ecosystem of the estimated increase in fecundity could be profound, although it was not evaluated in this work. Forage fish biomass is often considered to be critical in ecosystem structure and function and have beneficial effects on higher trophic levels (Cury et al., 2011). Research by Fuiman et al. (2015) has highlighted the potential importance of "egg boons" in marine systems; eggs rich in lipids and containing essential free fatty acids that are not able to be synthesized by fish but are consumed by predators likely play an important role in food webs.
Bagenal, T. B., and E. Braum.

1971. Eggs and early life history. In Methods for assessment of fish production in fresh waters, IBP Handbook 3, $2^{\text {nd }}$ ed. (W. E. Ricker, ed.), p. 159-181. Blackwell Scientific Publishing, Oxford, UK.

Brown-Peterson, N. J., and J. W. Warren.

2001. The reproductive biology of spotted seatrout, Cynoscion nebulosus, along the Mississippi Gulf Coast. Gulf Mex. Sci. 2001:61-73.

Brown-Peterson, N. J., D. M. Wyanski, F. Saborido-Rey, B. J. Macewicz, and S. K. Lowerre-Barbieri.

2011. A standardized terminology for describing reproductive development in fishes. Mar. Coast. Fish. 3:5270. Article

Combs, R. M.

1969. Embryogenesis, histology and organology of the ovary of Brevoortia patronus. Gulf Res. Rep. 2:333-434. Article

Cury, P. M., I. L. Boyd, S. Bonhommeau, T. Anker-Nilssen, R. J. M. Crawford, R. W. Furness, J. A. Mills, E. J. Murphy, H. Österblom, M. Paleczny, et al.

2011. Global seabird response to forage fish depletionone-third for the birds. Science 334:1703-1706. Article

Erisman, B. E., and L. G. Allen.

2006. Reproductive behaviour of a temperate serranid fish, Paralabrax clathratus (Girard), from Santa Catalina Island, California, U.S.A. J. Fish Biol. 68:157-184. Article

Fitzhugh, G. R, K. W. Shertzer, G. T. Kellison, and D. M. Wyanski.

2012. Review of size- and age-dependence in batch spawning: implications for stock assessment of fish species exhibiting indeterminate fecundity. Fish. Bull. 110:413-425. 
Fore, P. L.

1970. Eggs and larvae of the Gulf menhaden. In Report of the Bureau of Commercial Fisheries Biology Laboratory, Beaufort, N.C., for the fiscal year ending June 30, 1968. U.S. Fish Wildl. Serv., Circ. 341 (K. A. Henry, J. H. Kutkuhn, and staff), p. 11-13. Bur. Commer. Fish., U.S. Fish Wildl. Serv., U.S. Dep. Interior, Washington, DC.

Fuiman, L. A., T. L. Connelly, S. K. Lowerre-Barbieri, and J. W. McClelland.

2015. Egg boons: central components of marine fatty acid food webs. Ecology 96:362-372. Article

Ganias, K.

2013. Determining the indeterminate: evolving concepts and methods on the assessment of the fecundity pattern of fishes. Fish. Res. 138:23-30. Article

Ganias, K., S. Somarakis, A. Machias, and A. Theodorou.

2004. Pattern of oocyte development and batch fecundity in the Mediterranean sardine. Fish. Res. 67:13-23. Article

Ganias, K., S. K. Lowerre-Barbieri, and W. Cooper.

2015. Understanding the determinate-indeterminate fecundity dichotomy in fish populations using a temperature dependent oocyte growth model. J. Sea Res. 96:1-10. Article

Ganias, K., F.-A. Mouchlianitis, C. Nunes, A.-M. Costa, and M.-M. Angélico.

2017. A reassessment of the fecundity type of Atlantic horse mackerel (Trachurus trachurus) in Atlantic Iberian waters (ICES division IXa) shows that indeterminate spawners can cease recruiting oocytes during the spawning season. ICES J. Mar. Sci. 74:31-40. Article

Govoni, J. J.

1997. The association of the population recruitment of gulf menhaden, Brevoortia patronus, with Mississippi River discharge. J. Mar. Syst. 12:101-108. Article

Grier, H. J. and M. C. Uribe Aranzábal.

2009. The testis and spermatogenesis in telosts. In Reproductive biology and Phylogeny of fishes (agnathans and bony fishes), vol. 8A (B. G. M. Jamieson, ed.), p. 119142. Science Publishers, Enfield, NH.

Huntsman, G. R., and R. B. Chapoton.

1973. Biostatistical data acquisition in the menhaden fisheries. Trans. Am. Fish. Soc. 102:452-456. Article

Isaac-Nahum, V. J., R. de D. Cardoso, G. Servo, and C. L. del

B. Rossi-Wongtschowski.

1988. Aspects of the spawning biology of the Brazilian sardine, Sardinella brasiliensis (Steindachner, 1879), (Clupeidae). J. Fish Biol. 32:383-396. Article

Klibansky, N., and F. S. Scharf.

2015. Success and failure assessing gonad maturity in sequentially hermaphroditic fishes: comparisons between macroscopic and microscopic methods. J. Fish Biol. 87:930-957. Article

Kruschke, J. K.

2014. Doing Bayesian data analysis: a tutorial with R, JAGS, and Stan, $2^{\text {nd }}$ ed., 776 p. Academic Press, London.

Lajud, N.A., J. M. Díaz de Astarloa, and M. González-Castro.

2016. Reproduction of Brevoortia aurea (Spix \& Agassiz, 1829) (Actinopterygii: Clupeidae) in the Mar Chiquita Coastal Lagoon, Buenos Aires, Argentina. Neotrop. Ichthyol. 14:e150064. Article.

Lewis, R. M., and C. M. Roithmayr.

1981. Spawning and sexual maturity of Gulf menhaden, Brevoortia patronus. Fish. Bull. 78:947-951.
Lo, N. C. H., B. J. Macewicz, and D. A. Griffith.

2010. Spawning biomass of Pacific sardine (Sardinops sagax) off the U.S. in 2010. NOAA Tech. Memo. NMFSSWFSC-463, $35 \mathrm{p}$

Lowerre-Barbieri, S. K., K. Ganias, F. Saborido-Rey, H. Murua, and J. R. Hunter.

2011. Reproductive timing in marine fishes: variability, temporal scales, and methods. Mar. Coast. Fish. 3:71-91. Article

Macchi, G. J., and E. M. Acha.

2000. Spawning frequency and batch fecundity of Brazilian menhaden, Brevoortia aurea, in the Río de la Plata estuary off Argentina and Uruguay. Fish. Bull. 98:283-289.

McBride, R. S., R. Ferreri, E. K. Towle, J. M. Boucher, and G. Basilone.

2016. Yolked oocyte dynamics support agreement between determinate- and indeterminate-method estimates of annual fecundity for a northeastern United States population of American shad. PLoS ONE 11(10):e0164203. Article

Murua, H., and F. Saborido-Rey.

2003. Female reproductive strategies of marine fish species of the north Atlantic. J. Northwest Atl. Fish. Soc. 33:23-31.

Plummer, M.

2003. JAGS: a program for analysis of Bayesian graphical models using Gibbs sampling. In Proceedings of the $3^{\text {rd }}$ International workshop on distributed statistical computing (DSC 2003); Vienna, Austria, 20-22 March 2003 (K. Hornik, F. Leisch, and A. Zeileis, eds.), 1-10 p. Technische Universität Wien, Vienna, Austria. [Available from website.]

$\mathrm{R}$ Core Team.

2015. R: a language and environment for statistical computing. R Foundation for Statistical Computing, Vienna, Austria. [Available from website, accessed March 2015.]

Sagarese, S. R., M. A. Nuttall, T. M. Geers, M. V. Lauretta, J. F. Walter III, and J. E. Serafy.

2016. Quantifying the trophic importance of Gulf Menhaden within the northern Gulf of Mexico ecosystem Mar. Coast. Fish. 8:23-45. Article

Schueller, A. M., D. S. Vaughan, and J. W. Smith.

2012. Length-length conversions and weight-length relationships for Gulf menhaden (Brevoortia patronus) in the Gulf of Mexico. Gulf Mex. Sci. 30:54-59.

Shaw, R. F., W. J. Wiseman Jr., R. E. Turner, L. J. Rouse Jr., R. E. Condrey, and F. J. Kelly Jr.

1985. Transport of larval gulf menhaden Brevoortia patronus in continental shelf waters of western Louisiana: a hypothesis. Trans. Am. Fish. Soc. 114:452-460. Article

Sogard, S. M., D. E. Hoss, and J. J. Govoni.

1987. Density and depth distribution of larval gulf menhaden, Brevoortia patronus, Atlantic croaker, Micropogonias undulatus, and spot, Leiostomus xanthurus, in the northern Gulf of Mexico. Fish. Bull. 85:601-609.

Stockley, P., M. J. G. Gage, G. A. Parker, and A. P. Møller.

1997. Sperm competition in fishes: the evolution of testis size and ejaculate characteristics. Am. Nat. 149:933954. Article

Tsikliras, A. C., and E. Antonopoulou.

2006. Reproductive biology of round sardinella (Sardi- 
nella aurita) in the north-eastern Mediterranean. Sci. Mar. 70:281-290.

Tsikliras, A. C., E. Antonopoulou, and K. I. Stergiou.

2010. Spawning period of Mediterranean marine fishes. Rev. Fish Biol. Fish. 20:499-538. Article

Vaughan, D. S., K. W. Shertzer, and J. W. Smith.

2007. Gulf menhaden (Brevoortia patronus) in the U.S. Gulf of Mexico: fishery characteristics and biological reference points for management. Fish. Res. 83:263-275. Article
West, G.

1990. Methods of assessing ovarian development in fishes: a review. Aust. J. Mar. Freshw. Res. 41:199-222. Article Williams, E. H and K. W. Shertzer.

2015. Technical documentation of the Beaufort Assessment Model (BAM). NOAA Tech. Memo NMFS-SEFSC-671, 43 p. Article

Wootton, R. J.

1998. Ecology of teleost fishes, 2nd ed., 392 p. Kluwer Academic Publishers, Dordrecht, Netherlands. 